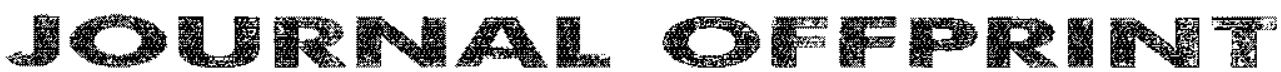

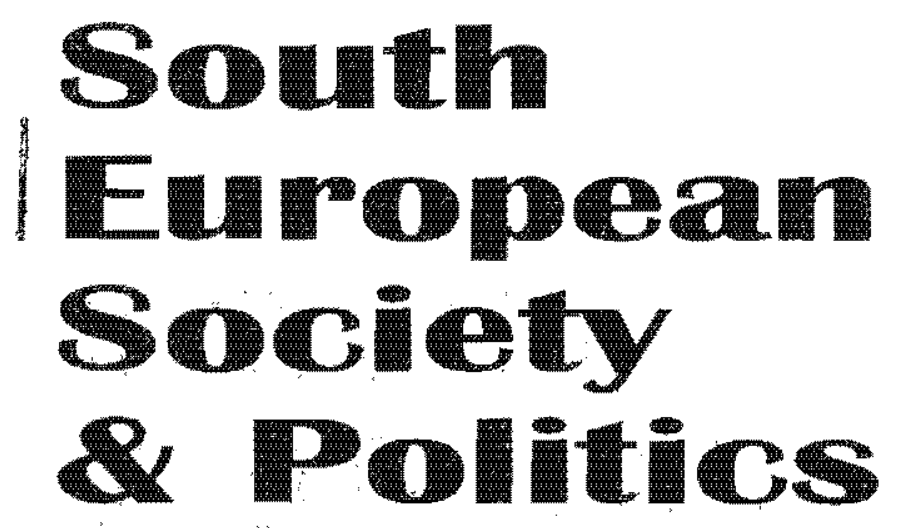

1

A FRANK CASS JOURNAL IS\$N $1360-8746$

UK and RoW Fronk Cos. Grown House, 47 Chase Side.;

London NV 4 SBP England

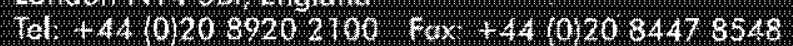

Email inis@irankeass.com

North Amerisa 5824 Ne Hassalo Street. Borland

OR 972133.3644, USA

Tel: 800944 6190 Fax: 5032808832 Email nitsejs65.com

for moro wormaton on this ou mal and other publicalians. poleose Wist our Website. WwW frankerss com 


\title{
A Small State and the European Union: Malta's EU Accession Experience
}

\author{
RODERICK PACE
}

\begin{abstract}
Malta's application to join the European Union has faced a number of difficulties. Despite numerous hurdles, the negotiarions are now bearing fruit and Malta is likely to be able to join the EU in 2004. However, there is norhing inevitable abour this process, given opposition from the Malrese Labour Party and uncertainty surrounding the ourcome of a referendum likely to take place in 2003. In this arricle, Malra's EU membership application is considered from the perspective of Malca as a small European stare. It is argued that Malta's size, though at first sight an obstacle to the islands' negotiaring position, may also be the source of credible arguments allowing the Maltese to win concessions from the EU. In making this argument, the arricle reviews and analyses Malta's accession experience in the light of Malta's domestic politics and the highly contesred nature of the European issue within that country's public sphere.
\end{abstract}

\section{INTRODUCTION}

In 1990, Malta applied to join the European Union. Six years later, in 1996 , because of a change of government in Valletta, the application was suspended. Following yet another change of government in 1998, Malta altered direction again and reactivared its application. Accession negotiations started in 2000 and are expected to be completed by the end of 2002. After this dare, the Malrese government will organize a referendum to give the Malrese people the final word on whether they want to join the Union or not. The ouccome of the referendum is difficult to predict, primarily because of the acute polarization that characterizes Malcese policics.

Due to its small size (population approximately 380,000 ), Malta's EU application has not commanded widespread atcention beyond its shores. except in negative specularions about its hyporherical handling of the rotating presidency of the Union or over its future role in EU external 
affairs.' That apart, EU membership has a number of ramifications, both for Malta and for the future of the EU's policies in the Mediterranean region. Moreover, Malta's EU membership presents an interesting case study for testing the main tenets of small state theories. Two main questions can be posed in this respect:

- What economic and political advantages does a small state seek to achieve from joining a regional integration project such as the EU?

- What is the likely effect on the EU of the accession of a number of small states (with Malta as a case study)?

This article focuses on the following major issues related to the Maltese application. These are discussed from both a small state and a Maltese perspective. The first issue to be considered is the link between Maltese domestic politics and the membership application, given that in Malta the issue of EU membership is a highly contested one. Second is the manner in which Malta, a small state, has used its relations with the EU to buttress its political and economic security, immaterial of which political party was in government or the dominant ideological view. And third, the article raises a number of questions about the 'strengths' of small states in confronting European integration and in negotiating with the EU.

\section{SMALL STATES AND EUROPEAN INTEGRATION}

It is very difficult to apply a coherent cheory to all small stares. Small states differ immensely in their physical and economic size, their level of economic development, their geographic location, their distance from large urban centres, population, size, their level of education, their culcure and in the nature of the security threats they face. At the same time there are some general norms of behaviour associated with small stares. It is also axiomatic to state that in trying to comprehend the behaviour of small states in international affarrs, one must not focus too heavily on regional and international dynamics at the expense of domestic political contexts, particularly when analysing relations with the EU. While the adoption of the acquis commtanautaire certainly has implications for a small applicant state's foreign policy, it also has a very practical impact on its domestic policies.

In internarional affairs, small states' interests are often better served by the international rule of law than by an anarchical international system based on the struggle for power. Hence they tend to exhibit a preference for international organizations and rule-based regimes, 
privileging collective action over non-alignment. However, their policies may not always lead to intended outcomes. This can be demonstrated with reference to the "hard security threats' that small states face. While alliances may appear as the rational answer to the small state's security dilemma, it may also result in the small state falling under the hegemony of a dominant power. Similarly, neutrality might give a small state a sense of security in peacerime, but might also fail completely in times of conflicr. As a consequence, it is difficult to be certain which is the most advantageous policy for a small state: neutrality or alliance?

From an economic perspective, small states lack a domestic market which is sufficiently large to permit the attainment of economies of scale in most sectors. Their external dependence is thus greater than that of large or middle-sized states. Two non-mutually exclusive policies can be pursued to overcome this permanent drawback: integration into the world economy using the multilateral approach of the World Trade Organization (WTO), for example; and/or integration within a regional trading bloc. In the latter case, however, there are various stages or forms of integration possible, ranging from a free trade area or a customs union to a common market or monetary union. The small state, as any other state, has to weigh up the costs and benefits of integration of this sort. This choice is not unconstrained by external factors. For example, while integration will restrict a small state's economic and political freedom, this must be balanced against the 'real' freedom it enjoys in the global system.

An additional advantage that small states derive from regional integration is linked to the management of their external economic and political environment, in so far as these are manageable. Integration permits individually insignificant states to achieve a critical mass enabling them to deal more effectively with the challenges of globalization and to participate in global governance. Regionalism can thus be seen as a response to globalization. Regionalization may enable a group of states to reach a sufficient 'critical mass' to make its regulation of global corporations and other mobile entities more effective. For instance, the European Union is much more able to respond to United Starcs policy as a group, than it would be able to as individual councries (Keohane and Nye 2001: 260).

The small state's security dilemma cannot be defined onedimensionally. It is a complex issue closely linked to its domestic economy, the level of economic development and the welfare of its citizens, the resilience of its political institutions, good governance, incernal stability as well as its external relarions, market access, economic aid, regional and international stability. European integration supplies 
small European states with a number of economic and political advantages. In locking European states into a co-operative structure, the EU acts as a stabilizing force at its periphery, with Enlargement serving to extend the system. The survival prospects of small states have increased as a result. Although it is true that states are often born of war, European history has shown that the existence and separate identities of small states have been threatened most or, indeed, obliterated in periods of war and imperialism.

European unity has also provided the basis for an increase in economic wealth. All European states have benefited from this, but small stares appear to have been most successful, due perhaps to their greater flexibility. The Union is based on the principle of solidarity and the transfer of economic aid to poorer regions. The small, developing states of Europe, such as Malta, Cyprus, Slovenia and the Baltic states, can shorten the time it takes for them to catch up economically with the help of such aid following the example of Ireland - provided they take advantage of the opporrunities presented by membership.

Hence, small European states have a triple interest in strengthening the process of European integration. Participacion in the process is materially beneficial to them, giving them greater weight in influencing policies and shaping events to their advantage and transforming them from otherwise ineffectual actors into potentially influential ones.

Anorher aspect of the role of small states in international affairs relates to their security concerns. By and large, the security aims of small states differ very little from those of larger and stronger states, other than in scale and in their comparatively lesser ability to help themselves. Small states seek to safeguard their security, the inviolability of the national territory against traditional military incursions and against 'softer' threats such as those posed by organized crime or environmental degradation. In a world characterized by globalization, their independence and identities are often challenged by a plethora of nonstate actors some of whom, such as transnational corporations, command economic resources that far dwarf the small state's own combined resources. In addition, small states tend to guard their identities jealously, given past histories of foreign domination. The link between their economic and political security is particularly strong in light of their dependence on external trade.

\section{MALTA AND THE EUROPEAN UNION}

Historically, Malta has not perceived EU membership as a threat to its identity. The idea of participaring in European integration was espoused 
and promored by Malta's political elite prior to independence in 1964 , as a priority of the Nationalist Party. It did not cross the Nationalist leaders' minds that they might be exchanging one type of hegemony for anorher in pursuing closer relations with the then EC. Relations with the Community were perceived as a means of enhancing prospects for economic growth, resulting in a positive knock-on effect on domestic stability, nascent democracy and security. Above all, this would help consolidate Malta's international identity and statehood. The EC was also perceived as a means of diversifying Malta's over-dependence on the UK. The Nationalist Government of the 1960 s understood that the liberal aims of the European Community, formed as it was by countries that subscribed to democratic principles and a market economy, fitted well with its own political vision, in a world afflicted by the deep ideological schisms of the cold war.

The major policy shift towards neutrality, defined in terms of nonalignment and 'third world socialism', which occurred after the 1971 Labour victory, altered the essence of this approach very little. Relations with the EC continued to be perceived as the key to Malta's economic prospects after the closure of the UK military bases in 1979. The Association Agreement with the Community, agreed in 1970, was to be both a means to prepare Malta for this 'great appointment with its historic desciny" and to sustain it afterwards (Development Plan, Office of the Prime Minister 1974: 49). 2 Together with these changes, Malta's formal assumption of a neurral status led the Nationalist Party to adopt support for EC membership as a means of safeguarding Malta's democracy and its market economy - and ultimately its Western orientation.' With the election of Dom Mintoff's Labour Party came the closure of the UK military bases and the MLP's ambivalent foreign policy, often perceived at the time to be drifting towards the communist bloc countries in the name of 'maintaining a stronger balance' between East and West.

Following the return to government by the Nationalist Party in 1987, Malta's EC membership ambitions could finally be pursued, but not without difficulties. Malta's neutrality was perceived as problemaric by an $E C$ already heading towards political union, despite the fact that the Community already included a neutral member state, namely Ireland (European Commission 1993; European Parliament 1988). Positively for Malia, this obstacle was overcome, thanks to the unexpected and dramatic changes that took place in Europe following the end of the cold war. These developments led to a reassessment of the relevance of neutrality, clearing the way for the entry of three more neutral states to the newly-named European Union in 1995, namely Auscria, Finland and Sweden. 
In the 1990 s, the nature of the security threats facing European states changed dramatically. Attention turned to the Balkans and to unsettled border and ethnic questions in the former Soviet Union. Meanwhile in the Mediterranean region, the other area of concern to Malta's security, there seemed to be greater stability despite the fact that the traditional crisis points were still active or, at best, semi-dormant. A number of developments gave cause for optimism at the time, such as the OsloMadrid Middle East Peace Process (1991), the Five + Five Dialogue in the Western Mediterranean, the Mediterranean Forum and most of all, the launching of the EU's Euro-Mediterranean Partnership in 1995. In 1994, NATO had also launched its Mediterranean Dialogue." The chances of a direct north-south military confrontation in the Mediterranean region, absent since the Suez intervention of 1956 , looked less probable because of the developments just summarized. The main 'new' challenges to the overall stability of the region arose from problems of illegal immigration, organized crime and illicit drug, arms and human trafficking, the proliferation of weapons of mass destruction and the destabilising effects of a collapse of the political order in one or more of the key southern littoral states under the impact of the Islamic Fundamentalist challenge.

A rational appraisal of the regional and international context in which Malta found irself at the end of the cold war shows that its most efficient policy response to the challenges emanating from them could be achieved through EC/EU membership. EU membership gives Malta the possibility of participating in the European decision-making process. This would not only help the country to influence the course of developments in the Mediterranean, but it would also increase its influence in the region, given that the Arab World would attribute more imporrance to it once it became an EU member state. In addition, as a former non-aligned and neutral, small country, Malta is excellently placed to play the role of honest broker in the politics of the region,

By contrast, outside the EU, Malta would be the smallest of at least 28 states with no direct influence in the capitals of the Union or indeed in the southern Medirerranean countries. In addition, the southern littoral states have recendy shown signs of increased unity, given efforts to revive the Greater Arab Maghreb Union and the Agadir Initiative, which seeks to create an Arab free rrade area. ${ }^{5}$ These developments may lead to increased political unity among the Arab countries, already loosely coalesced within the Arab League. Somewhat paradoxically, these initiatives might help to stabilize the Mediterranean region if pursued in the longer-term, but could at the same time diminish Malta's influence and role in the region if it does not join the EU. 


\section{MALTA'S EU APPLICATION IN HISTORICAL PERSPECTIVE}

The national debate on Malta's relations with the EEC began in 1961 , three years after the formation of the Community and three years prior to Malta's independence (Pace 2001). The significance of the founding of the Community for Malta was immediate, as Malta is situated just 60 miles from the EC's southernmost frontier. At the time, the Maltese political elite's primary concern was how to preserve the links with the UK until such time as the Maltese economy could be weaned off its overdependence on British military spending and investment. Integration with the EFC or EFTA held enormous potential for Malta. The potential for economic integration with North Africa, the other large proximate market, appeared remote. The countries of this region maintained strongly protectionist trade policies, and from a cultural angle, Malta as a European and predominantly Catholic country was perceived to have little in common with its southern neighbours, other than perhaps linguistically (the Maltese language is largely derived from Arabic). Nevertheless, Malta valued its links with North Africa from an economic and political security perspective.

The idea that Malta could forge some kind of relationship with the European Communiry was first suggested in 1958 by Dom Mintoff, then leader of the Malta Labour Party, in a letter to Lennox Boyd, head of the UK Labour Party delegation at a constitutional conference on Malra's independence (Malta Labour Party 1990: 198). It was also Mintoff who coined the slogan that Malta could aim to become a 'little Switzerland in the Mediterranean". This slogan was laid to rest for nearly three decades until the Labour Party resurrected it in the run up to the 1996 and the 1998 elections. In his letter to Lennox Boyd, Mintoff had also alluded to the idea that Malta could serve as a 'bridge' berween Europe and North Africa. This was also a theme developed by Malta's then Prime Minister, George Borg Olivier, in a speech he gave in 1965, when Malra joined the Council of Europe, and it still forms part of the broad rhetorical repertoire on both sides of the Maltese political divide.

Herbert Ganado introduced the issue of Maita's relations with the EC into the Maltese political debate in 1961, just prior to Britain's first application to join the European Community. At the time, the international context was rapidly changing. On 9 July 1961, the Athens Association Agreement was signed between the EEC and Greece, providing a first model for potential and similar future agreements between the Community and European non-member countries of the Mediterranean region. That month, Ireland, another small country economically dependent on the UK, applied for EC membership in 
response to the clear indications that the UK was about to do the same. On 10 August 1961 the UK applied for membership, raising concerns about its future relations with the Bricish Commonwealth. This matter was raised at the London Conference of Commonwealth Prime Ministers of 10 September 1962 (Nicholson and East, 1987).

Only two of these Commonwealth countries, namely Cyprus and Malta, were European and, for them, two out of four potential options were possible according to the Treaty of Rome. The first two, namely membership or an association agreement with the EEC on the Greek model ${ }^{8}$ were immediately applicable to Cyprus, which had become independent in August 1960, but not for Malta, which had not as yet acquired independence. For Malta, two other avenues were available, The first was based on Article 227 (now Article 299) of the Treaty, whereby Malta could be 'associated' with the EEC as an overseas territory of the UK. The second one was based on Article 131 (now Article 182), providing for association agreements to be concluded between the EEC and the 'non-European' countries and territories linked to the Member States."

The Maltese Government, which was seeking independence from the UK, rejected both options. Malca's preference was clearly stated by Prime Minister Borg Olivier while speaking to journalists on his arrival in London for the Commonwealth Prime Ministers' conference: 'We have expressed our wish that Malta joins the European Community, though we still do not have a formal application. We believe that eventually, Malta will join the Community, both in the event of the UK's membership and not. We too form part of Europe' (Department of Information 1962).

Following the rejection of the UK's first application and while Malta was busying itself first with negotiating independence and then with the consolidation of its newly acquired statehood, relations with the EC took a back seat. Interest revived in 1968 , owing to the pressure exerted on the Maltese authorities by the economic effects of the rundown of UK military forces in Malta. This led to a fresh imperus to stimulate and diversify the Maltese economy. Negotiarions with the EC were concluded in 1970 with the signarure of the EC-Malta Association Agreement. The porential of the agreement was summed up by Malta's Prime Minister:

The agreement offers incentives and encouragement which should be of considerable assistance to us in our efforts to diversify our economy and to place it on surer foundarions. ... The political significance of our association with the Community lies, for our part mainly in the establishment of yet another strong link with 
the democracies of Europe. ... We are also hopeful that in the course of time it could develop into fuller participation in a united Europe (Department of Information 1970).

The Agreement provided for two stages, each in principle covering a period of five years. At the end of the second stage, Malta was to establish a customs union with the EC. During the first phase, the Community agreed to reduce the common customs tariff (CCT) by 70 per cent on most manufactured goods imported from Malta and to dismantle nearly all quantitative restrictions. This was to cover all manufactured products, with the exception of some food items and a few textile and clothing goods which were subject to annual tariff quotas. The scope of the original agreement was widened by six protocols signed in the mid-1970s, two of which were prolonged after the first stage of the Agreement to the end of 1980. In 1974 Malta was also granted similar treatment to that enjoyed by countries coming under the EC's General System of Preferences (GSP).

However, the first stage of the Association Agreement ended without agreement on the second, which would lead to a customs union. This signalled the beginning of a stalemate in EC-Malta relations which was to last until 1987, with Malta requesting a 'Special Relationship' and the EC pressing for the start of negotiations on the second stage. During this period, political relations with the EC also deteriorated because of Malta's foreign policy stance and the uncertain state of Maltese democracy and human rights. EC-Malta relations ameliorated following the 1987 government change and the policy shift that accompanied it, leading eventually to Malta's membership application of July 1990.

\section{THE POLITICAL CONTEXT}

Malta's relations with the EU can be understood fully only in the contexc of Malta's domestic politics. The EU membership issue is highly contested in Maltese society. The governing Nationalist Party has favoured membership since the 1960 s, while the opposition Malta Labour Party (MLP) has vacillated between a pragmatism that does not rule out membership altogether and a more doctrinaire position that excludes the possibility for the foreseeable future. Currently the MLP favours a 'partnership' with the EU based on a free trade area - a EuroMediterranean Partnership agreement.

The backdrop to these opposing stances on EU-Malta relations is that Maltese politics has always been highly concested and since 1971 , has been dominated by the Nationalist Party-Laboux Party duopoly. These 
parties have alternated in government (see Table 1). In the general elections of the last three decades, electoral murnout has never dropped below 90 per cent of eligible voters. ${ }^{10}$ The major political parties own television and radio scations and both are deeply involved in the print media. Their potential for mobilizing the electorate, aided by Malta's territorial size, is therefore significant as the history of Maltese elections testifies. Hence the way the public debate on EU membership is taking place in Malta has a lot of deja vu about it and a photo-finish result in the referendum would not be out of the ordinary."

The effects of this political fissure are mostly negative, yet some of the more positive effects cannot be ignored. Beginning with the negative ones, the strong contestation has tended to unnecessarily dissipate national energies. The trained and qualified human resource of a small country has obvious physical and quantitative constraints linked to small size. At the same time, the demands made on this resource in a small country are in some cases similar to those placed on larger ones. In addition, economic progress diverts qualified human resources away from the public sphere to the business and economic secror. Meanwhile, the stare has still to maintain the 'vital' institutions of statehood. These include the police, the army, the judiciary, the national health service, the educational system, diplomatic representation overseas, the line ministries, a Central Bank, an array of new regulatory agencies that have been set up in response to privatization and liberalization and other similar organizations.

The practice of 'winner takes all' that has characterized successive changes of government in Malta means that key positions in government

TABLE 1

NATIONAL ELECTIONS. TURNOUT AND MAIORITIES SINCE MALTA'S INDEPENDENCE

\begin{tabular}{|c|c|c|c|c|c|c|}
\hline \multirow{2}{*}{$\begin{array}{l}\text { Narional } \\
\text { Election } \\
\text { Year }\end{array}$} & \multicolumn{2}{|c|}{ PARTY VOTES } & \multirow{2}{*}{$\begin{array}{c}\text { Turnour } \\
\text { Valid Vores } \\
\text { as \% of } \\
\text { Registered } \\
\text { Vorers }\end{array}$} & \multicolumn{3}{|c|}{ NumRer of Parlimantary SEATK } \\
\hline & $\begin{array}{c}\text { Nationalist } \\
\text { Party } \\
\text { \% of Firss Prefo }\end{array}$ & $\begin{array}{l}\text { Malca } \\
\text { Labour } \\
\text { Party } \\
\text { ce Vores cast }\end{array}$ & & $\begin{array}{c}\text { Nationalist } \\
\text { Party }\end{array}$ & $\begin{array}{l}\text { Malta } \\
\text { Labour } \\
\text { Parry }\end{array}$ & Orhers \\
\hline 1966 & 47.90 & 43.10 & 89.71 & 28 & 22 & nil \\
\hline 1971 & 48.00 & 50.80 & 92.40 & 27 & 28 & nil \\
\hline 1976 & 48.43 & 51.54 & 94,30 & 31 & 34 & nil \\
\hline 1981 & 50.92 & 49.07 & 95.00 & 31 & 34 & ni \\
\hline 1987 & 50.91 & 48.87 & 95.48 & 35 & 34 & nil \\
\hline 1992 & 51.78 & 47.69 & 95.30 & 34 & 31 & nil \\
\hline 1996 & 47.80 & 50.72 & 95.02 & 34 & 35 & nil \\
\hline 1998 & 51.81 & 46.97 & 94.10 & 35 & 30 & nil \\
\hline
\end{tabular}


at various levels are awarded to Party supporters. Thus, the efficiency of the public domain is impaired because the best available resources may nor be utilized. Moreover, political polarization spearheaded by a politically biased media has tended to obscure issues by disseminating exaggerated claims and counter claims, not least on the question of EU membership, leading to public uncertainty and undue pressures on the democratic institutions.

On the positive side, the duopoly has led to stable governments, which normally last for the whole legislative period. Furthermore, waferthin majorities, which successive governments have had to contend with over the past 32 years, mean that a Maltese government can ignore opposition demands, whether it considers them to be feasible or not, only at the risk of losing its majority at the next election. For this reason, in the context of EU membership, the government has been obliged to take on board a number of issues that were perceived to be threats to Malta's interests, immaterial of whether or not these threats were real or imagined, and likely or unlikely to materialize.

One such issue was whether the Maltese language would be admitted as an official EU language. Another question concerned the free movement of workers and the popular 'image' of the dangers of an overwhelming influx of 'foreign workers' when Malta joins the EU. Equally important were other issues such as the future of the ship repair and shipbuilding sectors, agriculture and fisheries and the removal of protective levies in trade with the EU. During the negotiations, the Maltese negotiators were pressurized in no small measure into including these demands in their negotiating brief and in trying to negoriate an appropriate package that would answer these populist demands. Two general stances were taken by the negotiators to achieve their aims. First, they successfully used Malta's small size to justify their demands for 'special treatment'. Second, they argued successfully that the requested concessions, considered to be 'major' from a Maltese perspective were in reality insignificant for the Union. The results of the negoriations show that small states may not be completely helpless when negoriating nembership.

Another important political development triggered by the $\mathrm{EU}$ membership bid concerns the increased level of consultation between the government and bodies representative of various sectors of society. EU membership is no longer perceived simply as a foreign policy issue. The Ministry of Foreign Affairs still takes the lead, but handles the EU as an issue that couches all aspects of narional society. In an attempr to achieve some consensus, the government set up the Malta-EU Action and steering Committce (MEUSAC). This Committee involves the so-called 
'constituted bodies' (such as the Malta Federation of Industries, the Chamber of Commerce and the Employers' Association), the trade unions, as well as many other organizations, totalling abour 130 in all and representing the special interests of their members.

MEUSAC discusses and approves draft negotiating position papers before these are transmitted to Cabinet for final approval. This process includes any changes in the negotiating position that may be necessary during the negotiations. Although it was placed under enormous time pressure, mainly due to the time lost when the Maltese application was suspended in 1996-98, often irritating the organizations concerned, MEUSAC has managed to introduce an unprecedented level of consultation into Malta's political system. The Labour Party was invited to sit on the Committee as a permanent 'core' member but refused. Despite this fact, it would be difficult for any government in the future to rule without consultation now that this practice has been introduced, even though it is not tied to any legal or constitutional provision.

The other development that can be attributed to the EU membership application is its impact on public policy. For example, compliance with the EU's acquis communautaire has put the environment at the top of the political agenda. The quest for EU membership has also instigated changes in other sectors. The need to remove customs tariffs led to the introduction of Value Added Tax (VAT) and a wholesale reform of Malra's antiquated tax system. Privatization, liberalization and the introduction of rules on fair competition and standardization have led to the establishment of semi-independent authorities to regulate various economic sectors. Protectionist barriers are rapidly being dismantled with the process to be completed (with the exception of agricultural imports) during 2003. The independence of the Central Bank has been strengthened. A hard look has been taken at the question of state aid to the shipyards (which are being restructured rapidly) and reforms of the agricultural and fisheries sectors have been introduced. In the social and labour fields, new rights for workers have been introduced, especially in the field of health and safery issues. These structural changes that have been introduced over the past five years would not have occurred in the absence of the EU membership application and the start of accession negotiations.

The final unsettled EU-related question, which also impacts on Malta's democratic system, concerns the referendum on EU membership. The Labour Party has declared that it will not be bound by its result As of mid-2002 there is wide speculation that the Labour Party may also instruct its supporters to boycott the referendum in an atrempt to invalidate or at least delegitimize its result. Apart from the negative 
effect that this stance is having on the membership debate, it also signifies a step backwards in terms of Malta's political development, a blow to the idea of 'direct democracy' that appears to be well suited to small polities such as Malta. In Malta's political history, only rwo national referenda have ever been held: the first on whether Malta should inregrate with the UK (1956) and the second on the independence Constitution (1964). The results of both are reproduced in Table 2. In recent years, some public pressure has been exerted on governments to organize more referenda, with a new law on referenda enacted in 1996.

\section{NEGOTIATING EU MEMBERSHIP}

The image of small states in international affairs tends to be one of puny weaklings in a world of 'heavyweight' states. However, empirical evidence supplied by Malta's membership negotiations shows that small states need nor be helpless. At the time of writing, 21 out of the 31 chapters of the EU acquis have been provisionally closed. These chapters are listed in Table 3. Malta occupies the bottom of the league among the applicant countries in terms of chapters provisionally closed. This cannot be attributed solely to the fact that Malta began its negotiations two years after the first group of applicants, but is also a consequence of the tough stance that the Maltese negotiators have taken.

Malta's approach is based on the notion that its small size qualifies it for special treatment when adopting key parts of the acquis conmunautaire. In other words 'smallness', perceived by many to be a serious handicap in negotiations, is being employed successfully to plead a 'special case'. Indeed, the obstacles that Malta has encountered during the negotiations often originate with orher applicanr states, such as Cyprus and Estonia. ${ }^{2}$ For example, Cyprus conceded to the EU's

TABLE 2

RESUITS OF MALTESE REFERENDA 11956 AND 1964 )

\begin{tabular}{lcccccc}
\hline & $\begin{array}{c}\text { Registered } \\
\text { Voters }\end{array}$ & $\begin{array}{c}\text { Votes } \\
\text { Cast }\end{array}$ & $\begin{array}{c}\text { Vores Cast } \\
\text { as\% of } \\
\text { Registered } \\
\text { Votes }\end{array}$ & $\begin{array}{c}\text { no } \\
\text { (\% indicared as of vores cast) }\end{array}$ \\
\hline $\begin{array}{c}1956 \text { Integration } \\
\text { with the UK }\end{array}$ & 152,823 & 90,343 & 59.12 & 20,177 & 67,607 & 2,559 \\
$\begin{array}{l}1964 \text { Independence } \\
\text { Constirution }\end{array}$ & 156,886 & 129,649 & 82.60 & 54,919 & 65,714 & 9,106 \\
\hline
\end{tabular}


TABLE 3

CHAPTERS OF THE UNION ACQUIS TEMPORARILY CLOSED AND CHAPTERS STILL TO BE CLOSED

Negotiating Chapters Temporarily Closed

June 2000

1. Chapter 15 Industrial Policy

2. Chapter 16 Small and Medium-sized Undertakings

3. Chapter 17 Science and Research

4. Chapter 18 Education and Training

5. Chapter 19 Telecommunications and Information Technologies

6. Chapter 26 External Relations

7. Chapter 27 Common Foreign and Security Policy

October 2000

8. Chapter 12 Statistics

9. Chapter 20 Culture and Audiovisual Policy

10. Chapter 23 Consumer and Health Protection

November 2000

11. Chapter 5 Company Law

12. Chapter 11 Economic and Monetary Union

March 2001

13. Chaprer 28 Financial Control

June 2001

14. Chapter 1 Free Movement of Goods

15. Chapter 2 Free Movement of Persons

16. Chapter 3 Free Movement of Services

17. Chaprer 14 Energy
October 2001

18. Chapter 9 Transport

November 2001

19. Chapter 13 Social Policy and Employment

December 2001

20. Chapter 4 Free Movement of Capital

June 2002

21. Chapter 24 Justice and Home Affairs

Chapters still to be closed (as of June 2002)

1. Chapter 6 Competition Policy

2. Chapter 8 Fisheries

3. Chapter 21 Regional Policy

4. Chapter 22 Environment

5 . Chapter 25 Customs Union

6. Chapter 29 Financial and Budgetary Provisions

7. Chapter 7 Agriculture

8. Chapter 10 Taxation

9. Chapter 30 Institutional Issues

10. Chapter 31 Others 
demands on the application of VAT to food and medicines, leading to EU pressure on Malta to follow suit. On the question of the purchase of property in Malta by non-residents and on the free movement of labour, Malta managed to secure a number of permanent derogations and transitional arrangements, despite the fact that other applicant states chose to accept the EU line. Similarly on the purchase of property by foreigners, Cyprus accepced transitional arrangements while Malta negotiated a permanent derogation involving a special arrangement for the purchase of secondary residences, restricting the purchase of such property for all EU nationals that have not resided on the island for at least five years.

From an EU perspective, when small states secure permanent derogations from the EU's acquis that correspond to one of their important concerns but leave the EU negligibly affected because such concessions are quantitacively unimportant, the EU is better off. A potential cause of future internal disagreement will have been removed at the same time as the security and stability of the small state is strengthened, and at no great expense. Thus, the derogations that Malta has obtained do not threaten to disrupt the internal market, are negligible when measured against the scale of the EU but are nevertheless of vital importance to Malta.

As to the negotiations, the chapter on External Relations and the Common Foreign and Security Policy (CFSP), which raises the issue of Malta's neurrality and which was once considered a crucial obstacle to membership, has been successfully closed wirhout Malta having to change its neutral status. This was possible, as participation in the EU's Common Defence and Security Policy remains voluntary.

Negotiations still have to be concluded on Chapter 6, Comperition, where the toughest question concerns state subsidies to the ship repair and shipbuilding yards. The chapter on customs duties also remains open because of a disagreement over agricultural levies, which the EU wants to see removed immediately, but which Malta wants to dismantle only after accession. Of all the chapters, however, the environment and agriculture chapters are probably the most contentious. In the area of taxation, Malta has asked that food and medicines, which are not currently subject to VAT in Malta, might continue to enjoy this treatment upon tnembership. Malta is citing as precedents similar rights enjoyed by the UK and Ireland. The EU, on the other hand, is resisting this demand.

The most salient results achieved by Malta, as viewed from a national perspective, are fourfold. First, the Maltese language, a unique and old language spoken and written by the majority of Maltese and derived 
from Arabic with substantial imports from European languages, has been accepted as an official language of the EU. This is a very important achievement considering that the anti-membership lobby had campaigned on the basis that Maltese would not be accepted as an official EU language.

Second, negotiations on the Free Movement of Capital led to Malta being allowed to retain on a permanent basis (notwithstanding the EU treaties), legislation in place on the date of accession limiting the acquisition of secondary residences by foreigners. The Maltese negotiators successfully argued, on the basis of Malta's restricted land area (316 square kilometres) and high population density - which at 1,911 persons per square kilometre is the highest in the world - that it should be allowed to retain restrictions on the purchase of property by foreigners, including EU citizens, on a non-discriminatory basis.

Thus EU citizens are to be allowed to own a secondary home in Malta only after prior authorization and provided they satisfy certain conditions as currently applied by the Maltese authorities (a threshold price of the property, for example). They will not be entitled to own more than one property. To own property freely, including property required in connection with a business activity, EU citizens are required to have resided permanently in Malta for a period of five years. These restrictions were needed to prevent a burst of property speculation, important given that the building area in Malta is so restricted. As Commissioner Verheugen said in December 2001, 'it cannot be in the interest of the EU that an ordinary Maltese family could find difficulty buying property in its own country'. ${ }^{13}$ This arrangement is to be included in a protocol attached to the Accession Treaty.

Third, on the question of the free movement of persons, Maltese citizens will enjoy complete free movement across the EU following accession. However, Malta has secured a seven-year transitional arrangement in which it may apply safeguards unilaterally on the right of EU citizens to seek employment in Malta. After this period, Malta can seek a remedy through the EU institutions. Restrictions on non-EU nationals may continue.

And fourth, the EU has conceded to Malta the management of a 25nautical mile conservation zone for an indefinite period in order to control fishing and help conserve fish stocks. EU member states are already allowed 12-mile zones from their shore baselines. In addition, Malta has been authorized to manage fishing in an outer ring beyond the 12 miles, which has traditionally been reserved exclusively for its own fishing industry, though within this ourer ring only boats smaller than 12 metres will be allowed to fish. The agreement safeguards the 
area from over-fishing by large trawlers whilst also protecting the small Maltese fishing sector, thus achieving social as well as environmental aims.

Similar arguments are being employed in other policy areas that are still under negotiation. On agriculcure, the Maltese approach is based on the fact that agricultural land in Malta is limited, highly fragmented and parcelled into many small-sized holdings that make meaningful economies of scale impossible. Moreover, the sector suffers from many natural limitations, such as shallow soil and lack of water. Furthermore, the agricultural sector is important for the preservation of what remains of Malta's rural environment, with obvious ramifications for the tourist industry. The EU has been ready in many cases to allow a departure from EU rules where this was dictated by Malta's small physical size, but made it clear at the same time that this concession should not be taken as a precedent by other member states or applicants.

\section{CONCLUSION}

This article has used a case study of Malta and its relations with the EU to demonstrate how a small state has tried to ensure its security in the global arena. It has shown how a small state tries to harness the energies of the Furopean Union to irs own advantage and how relations with the EU are linked to the small state's domestic politics. While the accession process affects its political and economic structures, the domestic political situation clearly has a bearing on the polirical preferences of small stares when confronting the EU. The EU-Malta negotiations offer evidence that the effect of a small state's lack of power can be minimized by the presentation of clear ideas and arguments, especially where these draw on principles of the Union and practical common sense considerations. Thus, when faced with the EU, small states are far from helpless.

\section{NOTES}

1. See, for example, Charlemagne, 'A Big-Country direcroire for Europe?' in The Economist, 23 March 2002: 'We all agree, surely, that the EU's rotaring six-month presidency has to go (imagine Malra ruming a 25 country Europe) .... :

2. 'One of the primary objectives of the plan is to increase Malta's productive activity to an exrent which would make it possible for Malta to dispense atrer 1979 with the economic returns accruing from defence arrangements negoriared with foreign powers' (Development Plon, Office of the Prime Minister, 1974: 49). The growh in comperitiveness and producriviry of the Maltese economy was to happen in an EC contexr (see pp.67 et seq.). See also Supplement to the Development Plan also published in 1974, pp.74-8 and the Development Plan 1981-85, pp.72-5. 
3. Motion approved by the National Executive of the Nationalist Party on 16 February 1979.

4. This was initially open to Egypt, Israel, Mauritania, Morocco and Tunisia. It was extended to Jordan in 1995 and ro Algeria in 2000.

5. The 'Agadir Initiative' to create a free trade area is supported by the EU. It was initiated in May 2001, involves Morocco, Egypt, Tunisia and Jordan and is open to all Arab countries which are members of the Arab League.

6. This is the way the principle was articulated by Malta's Prime Minister, Dr Borg Olivier, in 1965 while addressing the Parliamentary Assembiy of the Council of Europe in Strasbourg: 'We bring to our membership of this Council two factors which influence our outlook. One is our position in the centre of the Mediterranean and the other our membership of the Commonwealth. Our position in the Middle Sea causes us to take a natural interest in the North African coast and in events and developments there. ... Whilst as a European Country sharing a common culture, history and way of life, we naturally gravitate towards Europe .... .

7. Malta Taghna, Year VI, No.271, 25 March 1961.

8. The Rome Treaty setting up the European Economic Community, called on 'the other peoples of Europe who share their [the Founding Member States] ideal to join in their efforts'. Article 237 stated: 'Any European state may apply so become a member of the Community'. Article 238 provided: 'The Community may conclude with a third country, with a union of states or with an international organization, agreements creating an association involving reciprocal rights and obligations, joint actions and special procedures.'

9. Article 227 (3) of the Treaty Establishing the European Economic Community: 'The overseas countries and territories listed in Annex IV to this Treaty shall be the subject of the special arrangements for association described in Part IV of this Treaty.' Further, 273 (4) stated, 'The provisions of this Treaty shall apply to the European territories for whose external relations a Member State is responsible'. Article 131 established that the member states agree to associate with the Community the non-European countries and territories which have special relations with Belgium, France, Italy and the Netherlands.'

10. In the 1962 election the turnout was 90.77 per cent while in the last election held, that of 1998 , the turnout was 95.28 per cent. The highest turnout was registered in the 1987 election. As Hirczy (1995) points out, 'The Maltese clearly set an international record in electoral participation'.

11. In as much as newspaper surveys can be trusted and considering the close results that have rraditionally characterized Maltese election results (there are few referenda to analyse) and the margin of error in such surveys which tends to render them obsolete, the latest survey carried out by The Malta Independent on Sunday ( 9 June 2002) shows that 51.3 per cent would vote in favour of membership in a referendum, 29.3 per cent would vote against and 19 per cent would abstain.

12. The EU finds it convenienr to compare Malta's case with that of Cyprus.

13. Quoted in a report on the web-site of the Malta-EU information Centre, http://www. mic.org.mt/Malta-EU/results/fmoc_negs.htm

\section{REFERENCES}

European Commission (1993): 'Commission Opinion on Malta's Application for EU Membership', Bulletin of the European Communities, Supplement No.4, Brussels: Office for Official Publications of the European Community.

European Parliament (1988): Malta and Its Relations with the European Community, Report drawn up on behalf of the Political Affairs Committee, Document A2-0128/88, 29 June.

Department of Information (1962): Jr-Review, Malta, Sept.

Department of Information (1970): Malta Today V, 12, Malta, Dec. 
Hirczy, W. (1995): 'Explaining Near-Universal Turnout: The Case of Malta', European Journal of Political Research 27/2, pp.255-72.

Keohane, R.O. and J.S. Nye (eds.) (2001): Power and Interdependence, Third Edition, London, Longman.

Malta Labour Party (1990): Malta and the EEC: Economic and Social Aspects, Malta.

Nicholson, F. and R. East (1987): From the Six to the Twelve: The Enlargement of the European Communities, London: Longman.

Office of the Prime Minister (1974): Development Plan for Malta: 1973-1980, Malta.

Pace R. (2001): Microstate Security in the Global System: EU-Malta Relations, Malta: Midsea Books. 